\title{
Biomass and carbon stock, carbon sequestration potential under selected land use systems in punjab
}

\begin{abstract}
This study was designed to quantify individual carbon sequestration potential of tree based intercropping systems (E. tereticornis, $P$. deltoides and $T$. grandis) and also quantify biomass and carbon stock in a conventional sole cropped wheat system in north western district of Punjab state of India. The main aim of this work is to quantify above ground and below ground carbon pools within a tree based intercropping and in conventional agricultural systems. The results of this study revealed that maximum total biomass $\left(1311.82 \mathrm{t} \mathrm{ha}^{-1}\right)$, total carbon stock $\left(654.91 \mathrm{t} \mathrm{ha}^{-1}\right)$ and total carbon sequestration potential $\left(130.98 \mathrm{t} \mathrm{C} \mathrm{ha}^{-1} \mathrm{yr}^{-1}\right)$ was observed in pure E. tereticornis plantation followed by mixed (P. deltoides and T. grandis) plantations (210.29 tha ${ }^{1}, 109.11 \mathrm{t} \mathrm{ha}^{-1}$ and $\left.21.83 \mathrm{t} \mathrm{C} \mathrm{ha}^{-1} \mathrm{yr}^{-1}\right)$ and poplar based land use systems $(181.01 \mathrm{t}$ ha-1, 97.29 tha $^{-1}$ and $\left.18.59 \mathrm{t} \mathrm{C} \mathrm{ha}^{-1} \mathrm{yr}^{-1}\right)$. Whereas, total biomass $\left(12.80 \mathrm{t} \mathrm{ha}^{-1}\right)$ and carbon stocks $\left(6.78 \mathrm{t} \mathrm{ha}^{-1}\right)$ lowest recorded under pure agricultural based land use system. The results from this study will help to estimate levels of atmospheric $\mathrm{CO}_{2}$ that could be sequestered by tree based land use systems for this climatic region of Punjab. Therefore, an attempt has been made to collect the data on biomass, carbon stock and carbon sequestration potential in selected land use systems. The present findings may be used as baseline information for developing prediction models for probable effects of different land use, future intervention and sustainable management of land use systems in this region.
\end{abstract}

Keywords: biomass, carbon stock, carbon sequestration potential, land use systems
Volume 2 Issue 2 - 2018

\author{
Sarangle S,' Rajasekaran A, ${ }^{2}$ Benbi DK, ${ }^{3}$ \\ Chauhan $\mathrm{SK}^{4}$ \\ 'Himalayan Forest Research Institute, India \\ ${ }^{2}$ Institute of Forest Genetics \& Tree Breeding, India. \\ ${ }^{3}$ Department of Soil Sciences, Punjab Agricultural University, \\ India. \\ ${ }^{4}$ Central Arid Zone Research Institute-Regional Research \\ Station, India.
}

Correspondence: Sangeeta Sarangle, Himalayan Forest Research Institute, Panthaghati, Shimla- 171009, Himachal Pradesh, India, Email ssarangle@gmail.com

Received: October 20,2017 | Published: March 22, 2018

\section{Introduction}

Carbon dioxide increase is attributed mainly combustion of fossil fuel and deforestation worldwide. ${ }^{1,2}$ The current atmospheric carbon concentration is $397.60 \mathrm{ppm}^{3}$ The $\mathrm{CO}_{2}$ concentration and other greenhouse gases (GHGs) in the atmosphere have increased considerably and are set to rise further. Two major environmental issues of the world today's are climate change and biodiversity. Increase in atmospheric concentrations of greenhouse gasses (GHG), of which the most common is carbon dioxide $\left(\mathrm{CO}_{2}\right)$, is considered to be the primary cause of global warming. Deforestation, agriculture and other land-use changes practices have been the second largest contributors of greenhouses gases. ${ }^{4}$ Global climate is changing drastically as a result of natural as well as anthropogenic activities. Development as well as transportation activities increasing the concentration of gases especially carbon dioxide. ${ }^{5}$ Undoubtedly, climate change is the main global issues which getting higher attention from the scientific communities in recent years. Furthermore, carbon dioxide would be doubled in the coming years i.e., 2050 if the current rate of increase continues and this will lead to the world wide temperature rise of up to $2-4^{\circ} \mathrm{C}$. ${ }^{6}$ The global sea level will rise by $28-98 \mathrm{~cm}$ due to melting of polar ice, which would badly alter low-lying coastal countries (e.g. Bangladesh, Maldives, The Netherlands) existence and livelihoods pattern, a projection by ${ }^{6}$ revealed that by the end of $21^{\text {st }}$ century. Tree planting enhance soil productivity through physico chemical and ecological changes depending upon pumping of nutrients from lower horizon of soil to upper layer, the quality and quantity of litter reaching the top most layer of soil, litter decomposition rate and nutrient release pattern. In addition, planting of trees in agricultural field is a useful way to lock up the carbon in different components of tree and enhance the soil carbon status. ${ }^{7-9}$ The short rotation tree species play a major role in carbon sequestration in the soil reservoir. ${ }^{10}$ The agroforestry studies not only accumulated sixty per cent more carbon but a major portion of carbon is locked over a longer period than the mono cropping systems. ${ }^{11-17}$ Litter fall also adds to the soil organic matter (SOM) and there by enhances soil carbon sequestration, ${ }^{18} \mathrm{~A}$ greenhouse gas (GHG) mitigation strategy not found in conventional agricultural systems.

\section{Material and methods}

The study was conducted in 2012-2014 on three selected different tree-based land use systems and one pure wheat crop in the farmer's field at Taran Taran district of the Punjab state, India. The site is located at $31^{\circ} 05^{\prime}$ to $31^{\circ} 30^{\prime} 05^{\prime \prime} \mathrm{N}$ and $74^{\circ} 30^{\prime}$ to $75^{\circ} 15^{\prime} 05^{\prime \prime} \mathrm{E}$ longitude and at an altitude of $219 \mathrm{~m}$ a.s.l. which represent western agro-climatic region of the Punjab state. The climate is hot, with a long dry season from last week of September to first week of June and a monsoon season from July to September. Mean annual precipitation of this region is $545 \mathrm{~mm}$. Maximum range of temperature is $43^{\circ} \mathrm{C}$ and minimum $4.4^{\circ} \mathrm{C}$ across the work area. The soil of the study site was silty clay loam with $\mathrm{pH}$ of 7.74-8.11, available N, P and K contents were 122-181, $13-31$ and $257-430 \mathrm{~kg} / \mathrm{ha}$ at the study site. Land use systems selected/ available for evaluation in the area were (i) Tectona grandis + Populus deltoides (ii) Populus deltoides +Triticum aestivum (iii) Pure Triticum aestivum (iv) Pure Eucalyptus tereticornis plantation. For all tree species data collected at $3^{\text {rd }}, 4^{\text {th }}$ and $5^{\text {th }}$ year.

Analysis of data: For measuring carbon sequestration potential from different tree species following parameters were measured:

\section{Above ground biomass (AGB) of trees}

Tree height and diameter at breast height (DBH): To estimate 
biomass of different trees, non-destructive method was used. With the help of regression equation, biomass of different trees estimated on the basis of dbh and tree height. Height of the trees recorded with the help of Indian made Ravi's multimeter and dbh can be determined by digital caliper at 1.37 meter from the ground level.

\section{Carbon sequestration related parameters in plants}

Carbon concentration: Carbon concentration in different tree/crop components was determined by CHNS (carbon, hydrogen, nitrogen and sulphur) analyzer method. Plant samples which randomly collected (trees and wheat crop) were analyzed for carbon content. Above and below ground parts of tree/crop were estimated on CHNS analyzer to calculate the carbon storage in each component viz., stem, leaves, branches, bark and root of trees whereas in straw, grain and root of wheat crop.

Carbon stock/mass in plants: it is obtained by multiplying the dry weight of the different plant components by their average carbon concentration in each part of plant. The carbon stock in different plant components was then summed up to obtain total carbon stock in plants.

Long lived carbon storage: The exact life time of wood products is poorly known, but a reasonable assumption is that wood product life times are at least equal to the rotation length. The proportion of stem wood used as long-lived wood products is estimated to be $42 \%$. Longlived carbon storage in plants was therefore estimated by the formula which is given by Wang et al. ${ }^{19}$.

\section{Long-lived carbon storage = carbon mass in stem wood $\times 42 \%$}

Heat from biomass combustion: Short lived biomass is generally used as fuel which can replace fossil fuels. The weight of biomass fuel equals the total biomass weight minus the long lived stem weight. Since the heat released per unit weight of biomass is taken as $18 \times 10^{9}$ $\mathrm{J} /$ ton. Heat from biomass combustion was estimated by the formula which is given by Wang et al. ${ }^{19}$.

\section{Heat from biomass combustion= [Biomass - (Stem wood weight $\times 0.42) \times 18 \times 109$}

Carbon storage from coal combustion: The thermal efficiency of biomass combustion is only $60 \%$ of that achieved with fossil fuels. If the heat release from combustion of unit weight of coal is taken as 25 x $10^{6} \mathrm{~J} /$ ton and the carbon content of coal is $70 \%$, then carbon storage from coal substitution can be estimated. Carbon storage from coal substitution was estimated by the formula which is given by Wang et al. ${ }^{19}$.

Total amount of carbon sequestration in woody component of tree was estimated by adding long lived carbon storage in wood products and the carbon storage due to substitution biomass for coal. Total carbon sequestration was expressed in tha ${ }^{-1}$ under all land use systems.

\section{Results and discussion}

\section{Biomass production}

The results in Table 1 shows the variation in biomass level for different tree species components, viz., stem, branch, leaves, roots and bark at different ages as well as wheat crop under different land use systems. At the end of the study period the maximum stem biomass $\left(\mathrm{kg} \mathrm{tree}^{-1}\right)$ was recorded in P. deltoides $\left(176.50 \mathrm{~kg}^{\text {tree }}{ }^{-1}\right)$ followed by pure eucalyptus plantation $\left(132.42 \mathrm{~kg}\right.$ tree $\left.^{-1}\right)$, T. grandis $(66.70$ $\mathrm{kg}$ tree $^{-1}$ ) based land use systems after five years. Highest branch wood, leaf, roots and bark biomass $\left(\mathrm{kg} \mathrm{tree}^{-1}\right)$ were observed in pure eucalyptus plantation $\left(91.30,35.00,14.33\right.$ and $\left.22.14 \mathrm{~kg}^{-1} \mathrm{tree}^{-1}\right)$ while minimum biomass was recorded in T. grandis plantation 11.36, 3.57, 5.00 and $7.84 \mathrm{~kg}$ tree $^{-1}$ respectively. The biomass content of stem, branch wood, leaf, roots and bark depends upon number of factors, viz., growth pattern of the tree species, site quality of the region, type of soil on which trees are growing, tree age, cultural practices, frequent intercultural operations and moisture conservation and its interaction with roots of below ground crops have also helps towards increasing height and DBH of trees species. In pure eucalyptus plantations maximum biomass can be attributed due to high density of tree species. More number of trees per hectare further resulted in maximum branch and leaf biomass. In above ground parts of soil, more biomass is allocated which is reported by Swamy et al. ${ }^{20}$.

Table I Biomass (dry weight $\mathrm{kg}$ tree ${ }^{-1}$ ) of different components in timber tree species at different ages

\begin{tabular}{|c|c|c|c|c|c|c|c|c|c|}
\hline $\begin{array}{l}\text { Tree } \\
\text { components } \\
\text { tree species }\end{array}$ & $\begin{array}{l}\text { Age of } \\
\text { trees } \\
\text { (years) }\end{array}$ & $\begin{array}{l}\text { trees/ } \\
\text { ha }\end{array}$ & Stem & Branches & Leaves & Bark & Total AGB* & $\begin{array}{l}\text { (BGB**) } \\
\text { Roots }\end{array}$ & $\begin{array}{l}\text { Total } \\
\left(\mathrm{AGB} *+\mathrm{BGB}^{* *}\right)\end{array}$ \\
\hline P.deltoides & 3 & 714 & 100.09 & 11.63 & 8.80 & 8.21 & |28.74(91.92) & 9.18 & I37.92(98.47) \\
\hline E.tereticornis & 3 & 4444 & 41.28 & 38.33 & 10.05 & 8.05 & $97.70(434.18)$ & 7.93 & $105.63(469.42)$ \\
\hline T.grandis & 3 & 625 & 30.42 & 6.39 & 2.10 & 4.61 & $43.53(27.21)$ & 2.83 & $46.36(28.98)$ \\
\hline $\operatorname{LSD}(p=0.05)$ & & - & 5.13 & 6.38 & 0.90 & 0.81 & 12.07 & 1.04 & 12.28 \\
\hline P.deltoides & 4 & 714 & 142.03 & 16.58 & 11.69 & 12.14 & $182.43(130.26)$ & 16.45 & $198.89(\mid 42.01)$ \\
\hline E.tereticornis & 4 & 4444 & 83.17 & 75.77 & 21.82 & 15.27 & $196.02(87|| I)$. & 10.38 & $206.40(917.24)$ \\
\hline T.grandis & 4 & 625 & 47.27 & 9.94 & 3.13 & 6.38 & $66.72(41.7)$ & 3.85 & $70.57(44.11)$ \\
\hline $\operatorname{LSD}(p=0.05)$ & & - & 12.26 & 4.35 & 0.81 & 1.16 & 15.15 & 1.45 & $15.9 \mid$ \\
\hline P.deltoides & 5 & 714 & 176.50 & 16.80 & 12.06 & 14.90 & $220.26(157.27)$ & 21.72 & $241.98(172.77)$ \\
\hline E. tereticornis & 5 & 4444 & 132.42 & 91.30 & 35.00 & 22.14 & $280.86(I 248.4)$ & 14.33 & $295.18(1311.82)$ \\
\hline T.grandis & 5 & 625 & 66.70 & 11.36 & 3.57 & 7.84 & $89.45(55.91)$ & 5.00 & $94.46(59.04)$ \\
\hline $\operatorname{LSD}(p=0.05)$ & & - & 18.99 & 6.72 & 2.78 & 2.11 & 19.60 & 1.76 & 20.2 \\
\hline
\end{tabular}

*AGB $=$ Above ground biomass, ${ }^{* * B G B}=$ Below ground biomass, Values in parenthesis are $\mathrm{t} \mathrm{ha}^{-1}$ 
Table 2 Carbon stock ( $k g$ tree- $\left.{ }^{\prime}\right)$ of different timber tree species

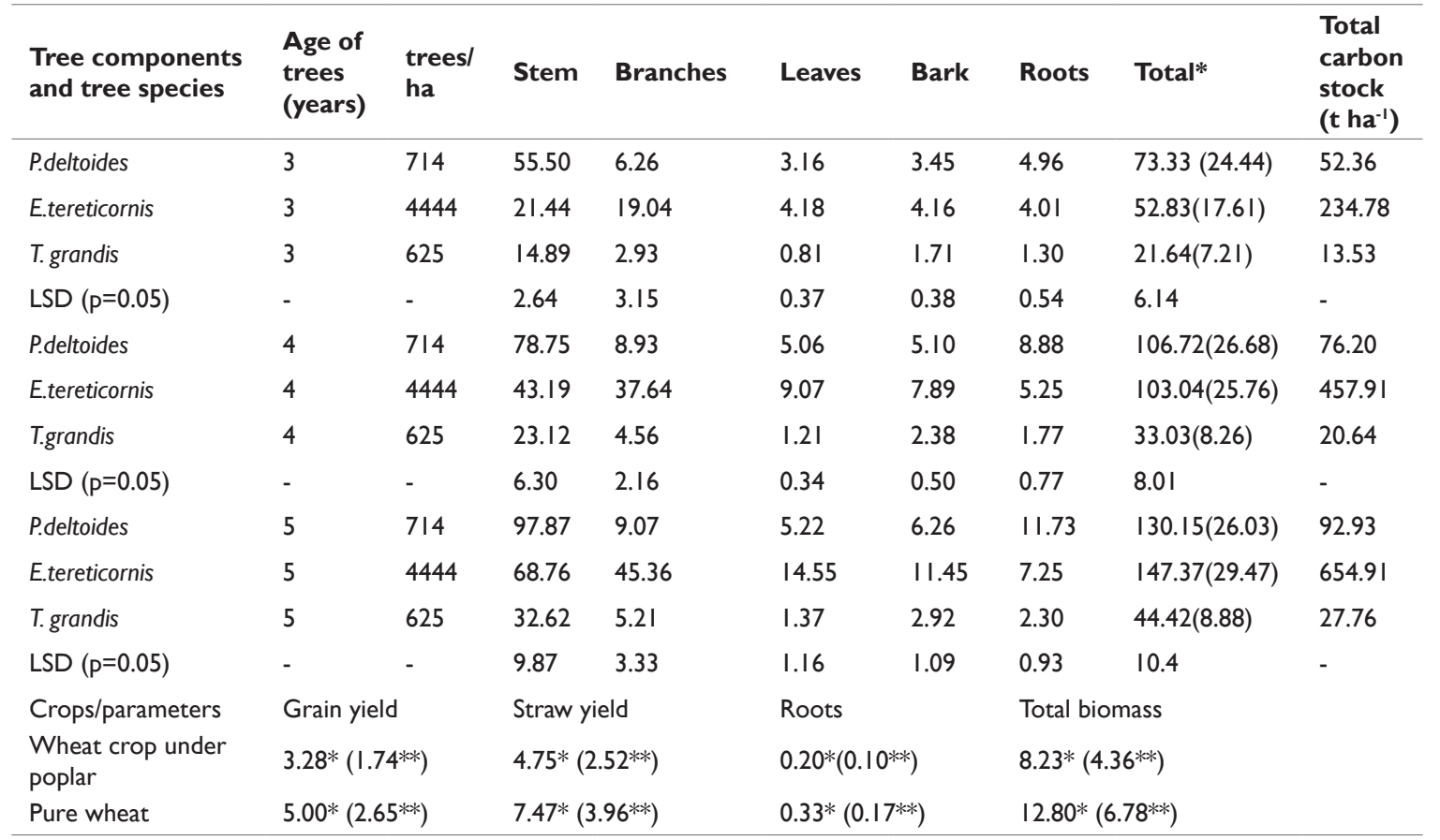

Carbon sequestration rate $\left(\mathrm{Kg} \mathrm{tree}^{-1} \mathrm{yr}^{-1}\right)$ in parentheses, ${ }^{*}$ Biomass $\left(\mathrm{tha}^{-1}\right)$, **Carbon stock (tha $\left.{ }^{-1}\right)$

Table 3 Total carbon sequestration potential $\left(\mathrm{t} C\right.$ ha $\left.^{-1} \mathrm{yr}^{-1}\right)$ of different tree species

\begin{tabular}{|c|c|c|c|c|c|c|c|c|c|}
\hline \multirow[b]{2}{*}{ Tree species } & \multicolumn{9}{|c|}{ Tree components } \\
\hline & $\begin{array}{l}\text { Age } \\
\text { oftrees } \\
\text { (years) }\end{array}$ & $\begin{array}{l}\text { trees/ } \\
\text { ha }\end{array}$ & Stem & Branches & Leaves & Bark & $\begin{array}{l}\text { Above } \\
\text { ground } \\
\text { biomass } \\
\text { carbon }\end{array}$ & $\begin{array}{l}\text { Below } \\
\text { ground } \\
\text { biomass } \\
\text { carbon }\end{array}$ & $\begin{array}{l}\text { Total } \\
\text { biomass } \\
\text { carbon }\end{array}$ \\
\hline P.deltoides & 3 & 714 & 13.21 & 1.49 & 0.91 & 0.82 & 16.43 & 1.18 & 17.61 \\
\hline E.tereticornis & 3 & 4444 & 31.75 & 28.21 & 6.19 & 6.16 & 72.31 & 5.94 & 78.25 \\
\hline T.grandis & 3 & 625 & 3.10 & 0.61 & 0.17 & 0.36 & 4.24 & 0.27 & 4.51 \\
\hline $\operatorname{LSD}(p=0.05)$ & - & - & 1.89 & 4.49 & 0.46 & 0.48 & 6.53 & 0.15 & 6.53 \\
\hline P. deltoides & 4 & 714 & 14.06 & 1.59 & 0.90 & 0.91 & 17.46 & 1.59 & 19.05 \\
\hline E.tereticornis & 4 & 4444 & 47.98 & 41.82 & 10.08 & 8.77 & 108.65 & 5.83 & I I4.48 \\
\hline T.grandis & 4 & 625 & 3.61 & 0.71 & 0.19 & 0.37 & 4.88 & 0.28 & 5.16 \\
\hline $\operatorname{LSD}(p=0.05)$ & - & - & 2.26 & 2.34 & 0.49 & 0.35 & 3.94 & 0.15 & 3.95 \\
\hline P.deltoides & 5 & 714 & 13.98 & 1.30 & 0.75 & 0.89 & 16.92 & 1.67 & 18.59 \\
\hline E.tereticornis & 5 & 4444 & 61.12 & 40.32 & 12.93 & 10.17 & 124.54 & 6.44 & 130.98 \\
\hline T.grandis & 5 & 625 & 4.08 & 0.65 & 0.20 & 0.40 & 5.27 & 0.29 & 5.55 \\
\hline LSD $(p=0.05)$ & - & - & 8.55 & 2.90 & 1.00 & 1.00 & 8.80 & 0.16 & 8.70 \\
\hline
\end{tabular}

Minimum stem biomass in T. grandis under mixed plantation can be attributed due to less number of trees per hectare and also due to slow growth of the tree species. In branch wood, leaf, roots and bark lowest biomass can be attributed due to self pruning ability of tree species. Above ground values of biomass in this study are comparable with those obtained ${ }^{21}$ for $P$. deltoides and $^{22}$ for Eucalyptus tree species. Total above ground biomass (Table 4) was found maximum in $T$. grandis $+P$. deltoides $\left(210.29\right.$ tha $\left.^{-1}\right)$ followed P. deltoides $+T$. aestivum $\left(181.01\right.$ tha $\left.^{-1}\right)$. The highest above ground biomass was recorded under pure eucalyptus plantation (1311.82 tha $\left.{ }^{-1}\right)$ and lowest under pure agricultural based land use system $\left(12.80\right.$ tha $\left.^{-1}\right)$.
Similar results recorded by Labata et al. ${ }^{23}$ in Philippines under mixed multi-storey land use system which had the greatest carbon storing potential. Maximum above and below ground biomass was studied in pure eucalyptus plantation (1248.14 and 63.68 tha $^{-1}$ ) followed by $T$. grandis $+P$. deltoides $\left(213.18\right.$ and 18.64 tha $\left.^{-1}\right)$, and P. deltoides $+T$. aestivum $\left(165.3,15.71\right.$ tha $\left.^{-1}\right)$ and the minimum was recorded in pure agricultural based land use system (12.47 and 0.33 tha $\left.^{-1}\right)$. In pure eucalyptus plantation, maximum biomass was observed due to high density plantation, growth pattern of the tree species, soil conditions on which trees were growing, intercultural operations and fertilizer requirements to the plantations. 
T. aestivum: Maximum crop biomass of T. aestivum was found in mono cropping whereas minimum when it was grown with tree species (Table 2); yield reduction under trees species is a common phenomenon which is recorded during study period. The reason for low crop biomass may be due to competition between trees and agricultural crop for the sharing of resources, viz., water, light and nutrients. Low yield of wheat crop under tree species has also been recorded. ${ }^{17,24-28}$

Table 4 Carbon sequestration features of four different land use systems

\begin{tabular}{|c|c|c|c|c|}
\hline \multirow{2}{*}{$\begin{array}{l}\text { Carbon sequestration } \\
\text { Features }\end{array}$} & \multicolumn{4}{|c|}{ Land use systems } \\
\hline & $\begin{array}{l}\text { (T. grandis+ } P \text {. } \\
\text { deltoides) }\end{array}$ & $\begin{array}{l}\text { (P. deltoides } \\
\text { +wheat crop) }\end{array}$ & $\begin{array}{l}\text { E. tereticornis } \\
\text { plantation }\end{array}$ & $\begin{array}{l}\text { Pure wheat } \\
\text { crop }\end{array}$ \\
\hline Above ground biomass ( $\left.\mathrm{t} \mathrm{ha}^{-1}\right)$ & 193.58 & 165.3 & 1248.14 & 12.47 \\
\hline Below ground biomass $\left(\mathrm{t} \mathrm{ha}^{-1}\right)$ & $16.7 \mid$ & |5.7| & 63.68 & 0.33 \\
\hline Total & 210.29 & 181.01 & $13 \mid 1.82$ & 12.80 \\
\hline Above carbon stock (t ha-1) & 100.33 & 88.81 & 622.69 & 6.61 \\
\hline Below carbon stock (t ha-1) & 8.78 & 8.48 & 32.22 & 0.17 \\
\hline Total & 109.11 & 97.29 & 654.91 & 6.78 \\
\hline AGCS* potential (t C ha-1 $\left.y r^{-1}\right)$ & 20.08 & 16.92 & 124.54 & - \\
\hline BGCS**potential (t C ha-1 $\left.\mathrm{yr}^{-1}\right)$ & $\mathrm{I} .75$ & 1.67 & 6.44 & - \\
\hline Total & 21.83 & 18.59 & 130.98 & - \\
\hline $\begin{array}{l}\text { Long-lived carbon storage in stem } \\
\text { (kg/tree) }\end{array}$ & $\begin{array}{l}54.80 \\
(37.91)\end{array}$ & $\begin{array}{l}41.10 \\
(29.35)\end{array}$ & $\begin{array}{l}28.88 \\
(128.34)\end{array}$ & - \\
\hline $\begin{array}{l}\text { Heat from biomass combustion } \\
\left(\times 10^{9} \text { Joule ha-1) }\right.\end{array}$ & $2,335.21$ & 1878.12 & $180 \mid 7.64$ & - \\
\hline $\begin{array}{l}\text { Carbon storage from coal combustion ( } \mathrm{t} \\
\mathrm{C} \mathrm{ha}^{-1} \text { ) }\end{array}$ & 39.23 & 31.55 & 302.7 & - \\
\hline
\end{tabular}

Above ground carbon sequestration*, below ground carbon sequestration**, in parenthesis the values in $\mathrm{t} c /$ ha

\section{Carbon stock (tree and crop) and sequestration potential (tree)}

Carbon concentration in each plant components was determined by CHNS analyzer. Carbon concentration in different components varied from 37.21-55.45 per cent. Stem wood of poplar tree showed maximum carbon concentration i.e. 55.45 per cent. The maximum carbon concentration in stem, branch, root, leaves and bark was estimated 55.45, 53.83, 53.01, 43.27 and 42.37 per cent respectively in poplar tree whereas in eucalyptus the concentration percentage is $51.93,49.68,50.59,41.58$ and 51.69 and in $T$. grandis the percentage in the following way: 48.91, 45.89,45.95, 38.52 and 37.21. Maximum carbon concentration in wheat crop 53.01 per cent was recorded in stem followed by grain and roots (53 and 50.74) respectively.

In stem carbon concentration was higher followed by branch wood and leaves of tree species. Similar results were also recorded. ${ }^{29-31}$ A similar pattern was studied by ${ }^{32}$ for Gmelina arborea. Carbon concentration in each parts of various species highly depends upon the ash content which further varies in different components of the trees viz., stem, branch, leaf etc. ${ }^{1,2,31,33}$ Above (stem, branch, leaf, bark ) and below ground (roots) carbon stocks $\left(\mathrm{kg} \mathrm{tree}^{-1}\right)$ at different ages of tree species in different land use systems are given in Table 2. The maximum total carbon stock after five years was observed in pure eucalyptus plantation for stem $\left(68.76 \mathrm{~kg} \mathrm{tree}^{-1}\right)$, branches $(45.36 \mathrm{~kg}$ tree $\left.^{-1}\right)$, leaf $\left(14.45 \mathrm{~kg} \mathrm{tree}^{-1}\right)$, bark $\left(11.45 \mathrm{~kg}\right.$ tree $\left.^{-1}\right)$ and roots $(7.25 \mathrm{~kg}$ tree $\left.^{-1}\right)$ followed by poplar for stem $\left(97.87 \mathrm{~kg} \mathrm{tree}^{-1}\right)$, branches $(9.07$ $\mathrm{kg}$ tree $\left.\mathrm{e}^{-1}\right)$, leaf $\left(5.22 \mathrm{~kg}\right.$ tree $\left.^{-1}\right)$, bark $\left(6.26 \mathrm{~kg}\right.$ tree $\left.{ }^{-1}\right)$, and roots $(11.73$ $\mathrm{kg}$ tree $\left.^{-1}\right)$. Minimum carbon stock after five year in teak stem was recorded $32.62 \mathrm{~kg}$ tree $^{-1}, 5.21 \mathrm{~kg}^{-1}$ tree $^{-1}$ (in branch wood), $1.37 \mathrm{~kg}$ tree (in leaf), $2.30 \mathrm{~kg}$ tree $^{-1}$ (in bark) and $2.30 \mathrm{~kg}^{\text {tree-1 }}$ (in roots). The lowest total carbon stock was estimated in pure wheat crop based land use system.

Total carbon stock of each land use system (Table 4) reveled that maximum total carbon stocks $\left(654.91\right.$ tha $\left.^{-1}\right)$ in pure eucalyptus plantation which is followed by $T$. grandis $+P$. deltoides (109.11 tha $\left.^{-1}\right)$ and $P$. deltoides + T. aestivum $\left(97.29\right.$ tha $\left.^{-1}\right)$ respectively. Total minimum carbon stocks were observed in pure wheat crop $(6.78$ tha $\left.{ }^{-1}\right)$. Carbon stocks are highly dependent on the tree density ${ }^{34}$ and carbon concentration in each and every component of tree species. Carbon storage can be high in complex agroforestry land use systems and productivity depends on so many factors such as tree age, structure and management of the planting system..$^{32,35,36}$ The results of the study also comparable with the findings of ${ }^{37}$ which reported that agroforestry land use system can store carbon in the range of 12-28 $\mathrm{Mg} \mathrm{ha}^{-1}$. Chauhan et al. ${ }^{16,17}$ also recorded higher carbon sequestration potential under agroforestry systems.

\section{Carbon sequestration potential}

Carbon stock is the absolute quantity of carbon held at the time of inventory, where as carbon sequestration rate refer, it is the way of removing carbon from the environment and depositing it in a reservoir. ${ }^{38}$ Therefore, total carbon sequestration potential and carbon sequestration rate of all the components of all three tree species were estimated in Table 3. The data from above and below ground biomass carbon ( $\mathrm{t} \mathrm{C} \mathrm{ha-} \mathrm{yr}^{-1}$ ) of different tree species at different ages was recorded during study period. Annual carbon sequestration (Table 4) was higher in eucalyptus plantation (130.98 $\left.\mathrm{t} \mathrm{C} \mathrm{ha}^{-1} \mathrm{yr}^{-1}\right)$ which was followed by poplar $\left(18.59 \mathrm{t} \mathrm{C} \mathrm{ha-}^{-1} \mathrm{yr}^{-1}\right)$ and mixed plantation $(21.83 \mathrm{t}$ $\left.\mathrm{C} \mathrm{ha}^{-1} \mathrm{yr}^{-1}\right)$. 


\section{Carbon sequestration features}

Long lived carbon storage in tree stem and carbon storage from coal substitution through branches and twigs/leaves of different tree species at different ages have been calculated in Table 4. During study period, maximum values in long lived carbon storage were recorded in tree based land use systems: In $T$. grandis $+P$. deltoides $(37.91$ t C $\left.\mathrm{ha}^{-1}\right), P$. deltoides + wheat crop $(29.35 \mathrm{t} \mathrm{C} \mathrm{ha-1})$ and pure eucalyptus plantation (128.34 t C ha ${ }^{-1}$ ) respectively (Table 4). The maximum heat from biomass combustion and carbon storage from coal substitute was studied in pure eucalyptus plantation $18017.64 \times 10^{9}$ and 302.7 t C ha ${ }^{-1}$ followed by T. grandis $+P$. deltoides $2,335.21 \times 10^{9}$ and 39.23 t $\mathrm{Cha}^{-1}$ and P. deltoides + wheat crop $1878.12 \times 10^{9}$ and $31.55 \mathrm{t} \mathrm{Cha}^{-1}$ respectively.

Considering only the woody components of various agroforestry land use systems, for long term carbon storage and for coal substitution, the value of carbon sequestration was highest recorded in eucalyptus plantation followed by mixed land use system. Higher deposition of biomass in stems portion of $P$. deltoides sequester higher amount of carbon for a life time of the species. Thus, it sequesters the carbon for longer time after falling as compared to the carbon stored in leaves and branch biomass of tree species. The results are again in comparable with the findings of ${ }^{19,39}$ also studied similar results with different tree species of poplar and Eeythrina poeppigiana. Chauhan et al. ${ }^{17}$ reported the heat from biomass combustion and carbon storage from coal substituted of timber was higher in the block plantation $(18.67 \mathrm{t} \mathrm{C} / \mathrm{ha})$ as compared with boundary plantation $(4.43 \mathrm{t} \mathrm{C} / \mathrm{ha})$ of poplar tree in Punjab, India.

\section{Conclusion}

The work of this study prove that tree under different land use systems acts as storehouse of carbon by storing carbon in their tissues as biomass and thereby reducing the amount of atmospheric $\mathrm{CO}_{2}$. The study strongly reinforces the pure plantation, agroforestry and mixed plantations are better options than the pure agricultural land use system, not for carbon combat but for sustainable productivity. The higher productivity of all tree based land use systems was reported in this study with higher biomass, carbon stock and carbon sequestration rate and potential. Despite this pioneering study, more research is needed under different land use systems i.e pure, mixed plantations, agroforestry and under pure crop based land use systems on this ground of Punjab, India.

\section{Acknowledgements}

None.

\section{Conflicts of interest}

Authors declare there is no conflict of interest.

\section{References}

1. Jana BK, Biswas S, Majumder M, et al. Carbon sequestration rate and above ground biomass carbon potential of four young species. Journal of Environmental Science and Engineering. 2009;1(2):015-024.

2. Jana BK, Biswas S, Majumder M, et al. Carbon sequestration rate and aboveground biomass carbon potential of four young species. Journal of Ecology and Natural Environment. 2009;1(2):15-24.

3. National oceanic and atmospheric administration. USA: Earth System Research Laboratory; 2014
4. IPCC. Mitigation of Climate Change. Contribution of Working Group III to the Fifth Assessment Report of the Intergovernmental Panel on Climate Change. In: Edenhofer O, Pichs Madruga R, Sokona Y, Farahani E, Kadner S, Seyboth K, Adler A, Baum I, Brunner S, Eickemeier P, Kriemann B, Savolainen J, Schlömer S, Stechow CV, Zwickel T, Minx JC, editors. USA: Cambridge University Press; 2014.

5. Pragasan LA, Karthick A. Carbon stock sequestered by tree plantations in university campus at Coimbatore, India. International Journal of Environmental Science. 2013;3(5):1700-1710.

6. IPCC. Summary for Policymakers. In: Stocker TF, Qin D, Plattner GK, Tignor M, Allen SK, Boschung J, Nauels A, Xia Y, Bex V, Midgley PM, editors. Climate Change 2013: The Physical Science Basis. Contribution of Working Group I to the Fifth Assessment Report of the Intergovernmental Panel on Climate Change. UK: Cambridge University Press; 2013. p. 3-32.

7. Dhillon RS, Wuehlisch G. Global warming and mitigation through forestry and agroforestry. Indian Journal of Agroforestry. 2011;13:1-9.

8. Rytter RM. The potential of willow and poplar plantation as carbon sinks in Sweden. Biomass and Bioenergy. 2012;36:86-95.

9. Saha R, Jha P. Carbon sequestration potentials of agroforestry systems under climate change scenariobrief review with special emphasis on northeastern hill regions. Journal of Agricultural Physics. 2012;12(2):100-106.

10. Chauhan SK, Gupta N, Yadav S, et al. Biomass and carbon allocation in different parts of agroforestry tree species. Indian Forester. 2009;135(7):981-992.

11. Nair PKR, Kumar BM, Nair VD. Agroforestry as a strategy for carbonsequestration. Journal of Plant Nutrition and Soil Science. 2009;172(1):10-23.

12. Nair PKR, Nair VD, Kumar BM, et al. Carbon sequestration in agroforestry systems. Advances in Agronomy.2010;108:237-307.

13. Benbi DK. Brar K, Toor AS, et al. Soil carbon pools under poplar-based agroforestry, rice-wheat, and maize-wheat cropping systems in semi-arid India. Nutrient Cycling and Agroecosystem. 2012;92(1):92-107.

14. Jose S, Bardhan S. Agroforestry for biomass production and carbon sequestration: an overview. Agroforestry Systems. 2012;86:105-111.

15. Chauhan SK, Sharma SC, Beri V, et al. Accounting poplar and wheat productivity for carbon sequestration in agri-silvicultural system. Indian Forester. 2010;136(9):1174-1182.

16. Chauhan SK, Gupta N, Walia R, et al. Biomass and carbon sequestration potential of poplar-wheat inter-cropping system in irrigated agroecosystem in India. Journal of Agricultural Science and Techology. $2011 ; 1: 575-586$

17. Chauhan SK, Sharma R, Singh B, et al. Biomass production, carbon sequestration and economics of on-farm poplar plantations in Punjab, India. Journal of Applied and Natural Science. 2015;7(1):452-458.

18. Sanderman J, Farquharson R, Baldock J. Soil carbon sequestration potential: A review for Australian agriculture. Australia: Department of Climate Change and Energy Efficiency, CSIRO; 2009.

19. Wang X, Fenz Z. Atmospheric carbon sequestration through agroforestry in China. Energy. 1995;20(2):117-121.

20. Swamy SL, Mishra A, Puri S. Biomass production and root distribution of Gmelina arborea under an agrisilvicultre system in sub-humid tropics of central India. New Forests. 2003;26(2):167-186.

21. Lodhiyal LS, Singh RP, Singh SP. Structure and function of an age series of poplar plantation in Central Himalaya. I. dry matter dynamics. Annals of Botany. 1995;76(2):191-199.

22. Pandey MC, Tandon VN, Rawat HS. Organic matter production and 
distribution of nutrient in eucalyptus hybrid plantation ecosystem in Karnataka. Indian Forester. 1987;114(11):713-724.

23. Labata MM, Aranico EC, Tabaranza ACE, et al. Carbon stock assessment of three selected agroforestry systems in Bukidnon, Philippines. Advances in Environmental Sciences. 2012;4(1):5-11.

24. Sharma KK. Wheat cultivation in association with Acacia nilotica (2) Wild ex. Del. Field bund plantation-a case study. Agroforestry systems. 1992;17(1):43-51.

25. Puri S, Bangarwa KS. Effects of trees on the yield of irrigated wheat crop in semi-arid regions. Agroforestry Systems. 1992;20(3):229-241.

26. Dhillon GPS, Dhanda RS, Dhillon MS. Performance of wheat under scattered trees of kiker (Acacia nilotica) under rainfed condition in Punjab (India). Indian Forester. 1998;124(1):48-53.

27. Nandal DPS, Singh RR. Productivity of different cropping sequences in Dalbergia sissoo Roxb. Based agro-silviculture system. Indian journal of Forestry. 2001;24:433-436.

28. Chauhan SK, Brar MS, Sharma R. Performance of poplar (Populus deltoides Marsh) and its effect on wheat yield under agroforestry system in irrigated agro-ecosystem. India Caspian Journal of Environmental Sciences. 201210(1):53-60.

29. Navar J. Allometric equations for tree species and carbon stocks for forests of Northwestern Mexico. Forest Ecology and Management. 2009;257(2):427-434.

30. Fonseca W, Alice FE, Benayas JMR. Carbon accumulation and aboveground and belowground biomass and soil of different age native forest plantations in the humid tropical low lands of Costa Rica. New Forests. 2012;43(2):197-211.
31. Nasir RW, Khwaja NQ. Carbon Per cent in Different Components of Tree Species and Soil Organic Carbon Pool Under these Tree Species in Kashmir Valley. Current World Environment. 2014;9(1):174-181.

32. Swamy SL, Puri S. Biomass production and carbon sequestration of Gmelina arborea in plantation and agroforestry system in India. Agroforestry systems. 2005;64(3):181-195.

33. Negi JDS, Manhas RK, Chauhan PS. Carbon allocation in different components of some tree species of India: a new approach for carbon estimation. Current Science. 2003;85(11):1528-1531.

34. Pragasan LA. Carbon Stock Assessment in the Vegetation of the Chitteri Reserve Forest of the Eastern Ghats in India Based on Non-Destructive Method Using Tree Inventory Data. Earth Science \& Climatic Change. 2014.

35. Oelbermann M, Voroney RP, Gordon AM. Carbon sequestration in tropical and temperate agroforestry systems. A review with examples from Costa Rica and Southern Canada. Agriculture, Ecosystem and Environment. 2004;104(3):359-377.

36. Tumwebaze SB, Bevilacqua E, Briggs R, et al. Soil organic carbon under a linear simultaneous agroforestry system in Uganda. Agroforestry Systems. 2012;84(1):11-23.

37. Albrecht A, Kandji ST. Carbon sequestration in tropical agroforestry system. Agriculture, Ecosystems and Environment. 2003;99(1-3):15-27.

38. Takimoto A, Nair VD, Nair PKR. Contribution of trees to soil carbon sequestration under agroforestry systems in the West African Sahel. Agroforestry Systems. 2009;76(1):11-25.

39. Chesney PEK, Nygren P. Fine roots and nodule dynamics of Erthrina poepigiana in alley cropping system in Costa Rice. Agroforestry systems. 2002;56(3):256-269. 